\title{
Seasonal changes of foraging habitats and prey species in the Japanese Crested Ibis Nipponia nippon reintroduced on Sado Island, Japan
}

\author{
CHIHIRO ENDO and HISASHI NAGATA
}

\begin{abstract}
Summary
Seasonal foraging habitats, prey species and foraging frequency of Japanese Crested Ibis Nipponia nippon in farmland were studied one year after its reintroduction on Sado Island, Japan. Paddies were the main foraging habitat in spring, early summer, autumn and winter. In late summer, ibises often used levees around paddies, grasslands, uncropped paddies and abandoned paddies. Small invertebrates were important prey components in terms of frequency $(70-90 \%)$ throughout the year. Ibises took Misgurnus loaches (less than $20 \%$ of prey captured) throughout the year; the capture rate of loaches in ditches was especially high in winter. Ibises depended on terrestrial invertebrates, including earthworms, particularly in late summer. No clear correlations between the rate of capture for each prey species and the proportion of habitat use in each season were detected. However, abandoned and uncropped paddies provided suitable habitats for the ibis because human disturbance was relatively low and the rate of capture for each prey type was relatively high throughout the year. Management of grass height in grasslands and on levees around the paddies will be effective in ensuring the availability of foraging habitats in late summer. Seasonal changes in the availability of foraging habitats in farmland ecosystems should be considered when designing effective management strategies for the establishment of Japanese Crested Ibis populations.
\end{abstract}

\section{Introduction}

The habitat conditions required for the successful reintroduction of a threatened species are a key issue in reintroduction biology (Armstrong and Seddon 2007). When habitat modifications have been extensive and the original ecosystem has been lost, it is important to monitor reintroduced populations to assess their pattern of habitat use and to understand limiting factors that influence their habitat selection.

The Japanese Crested Ibis Nipponia nippon is endemic to east Asia and was historically widespread throughout Russia, China, Korea, Taiwan and Japan. The population of Japanese Crested Ibis declined severely in the middle of the last century (BirdLife International 2001, Yamashina and Nakanishi 1983) because of changes in land use and human activities, such as the use of fertilisers and pesticides, the drying of paddies during winter, and direct hunting ( $\mathrm{Li}$ et al. 2002, 2009). It is now extinct in almost all of its former range and in May 1981, following three years of nationwide surveys in China, only seven birds (four adults and three chicks) were found in the wild. Wild Japanese Crested Ibis populations became extinct in 1981 in Japan when the last five remaining individuals were taken into captivity. By June 2002, conservation efforts resulted in the wild population in China reaching 140 birds and maintaining a steady increase. The captive population (in two breeding centres) was over 130 birds and also increasing. In 2008 Japanese Crested Ibises were reintroduced onto Sado Island, Japan. 
Paddies are one of the most important foraging habitats for the Japanese Crested Ibis as well as for various farmland birds (Li et al. 2002, Maeda 2001, Amano et al. 2008, Elphick 2010, Fujioka et al. 2010). Sado Island, the last area where wild Japanese Crested Ibis occurred, contains a large area of paddies that provide potential foraging habitats for the ibis. However, land use and agricultural practices on Sado Island have changed since the 1950s. Various attempts to create suitable foraging habitats for Japanese Crested Ibis preceded their reintroduction, but the effectiveness of these attempts was not clear.

In paddies, shallow water is retained during the growing period of rice plants, but they are usually drained before harvest, providing habitats for waterbirds during spring and summer before harvest and for land birds after the harvest (Maeda 2001). Amano et al. (2008) showed that spatial and temporal heterogeneity in paddies provides habitats for different avian species in winter and summer. In addition to the seasonal changes in water levels in paddies, the frequency of human activity and the growth of rice plants (height and density) seem to affect ibis foraging behaviour as well as that of waterbirds in paddies (Fujioka et al. 2001, Elphick 2010). To develop effective management practices during the reintroduction programme, it was necessary to understand the seasonal pattern of habitat use by Japanese Crested Ibis in regard to the heterogeneity of paddies, and to evaluate habitat conditions on the island.

The aim of this work was to determine seasonal use of foraging habitats and prey species and to compare foraging frequency among habitats for reintroduced ibises. This information will contribute to the design of habitat management strategies for the maintenance of viable Japanese Crested Ibis populations with implications for conservation of various avian species in farmland areas.

\section{Methods}

\section{Field observations}

Sado Island is located in the Sea of Japan, about $40 \mathrm{~km}$ off the coast of the Niigata city. On Sado Island, the first release of 10 individuals of the Japanese Crested Ibis was carried out in September 2008, and the second release of 20 birds occurred in September 2009. Field observations were conducted for four days every two weeks from July 2009 to July 2010. During May 2010, foraging behaviour of the ibises could not be observed because they dispersed to breeding areas.

On Sado Island, rice is usually planted in May and harvested from late September to October. Most paddies retain shallow water from March to June and experience intermittent dry and wet treatments several times during July and August before harvest. In winter, paddies are usually drained. Each paddy is surrounded and delimited by a levee. The average levee is $45 \mathrm{~cm}$ wide and $50 \mathrm{~cm}$ high.

Paddies were the main foraging habitat of Japanese Crested Ibis throughout the year, except during the period from late July to early October when the birds cannot enter because of the height and density of rice plants. In late October, ibises began using paddies again after the rice was harvested. Five seasons were defined within one year: spring (March and April; the period when paddies retain shallow water before rice planting), early summer (May to early July; the main growing period for rice), late summer (late July to September; the period when ibises did not forage in paddies), autumn (October and November; the period after harvest) and winter (December to February; the main period of snowfall).

Observations were undertaken from the time of the birds leaving their roost sites in the early morning until they returned to their roosting areas at sunset, a period spanning o5hoo-19hoo during early and late summer, o6hoo-18hoo during spring and autumn, and o7hoo-17hoo during winter. All observations were conducted by the author (CE). During observations, we tried to follow individual flight paths after the ibises left their roost to detect foraging sites. When we found ibises foraging, the habitat type and foraging behaviour of each individual was observed from a car using a telescope (Nikon ED). The observation point was located at a distance $>100 \mathrm{~m}$ away from the ibis being observed. 
Foraging habitats were categorised as paddy, abandoned paddy, uncropped paddy, levee around a paddy, ditch located inside a paddy, and grassland. Abandoned paddies were fallow fields and were usually filled with water and covered with grass. Uncropped paddies were fallow fields managed by farmers. They were filled with water after tilling and were not covered with plants in most cases. Foraging was categorised into behavioural events: searching (probing or gleaning), swallowing, and walking.

We developed the dataset of foraging behaviour by observing four males from the first release and 12 individuals from the second release. The four males from the first release were observed from July 2009 to September 2009 because these were the only birds that were settled on Sado Island. After the second release, 12 individuals from the second release and two males from the first release formed a group. We observed this group and the remaining two males from the first release. Each individual was identified by a uniquely coloured ring.

For each foraging site, data collection was completed by the time the birds ceased foraging and flew away. Foraging sessions were defined as a sequence of foraging behaviours. The duration ranged from three to 30 minutes. Foraging sessions were recorded for each focal individual which was selected at random. Observations continued until birds ceased foraging. The time of each behavioural event, the prey species captured, and the habitat type were recorded using eventrecording software (ODLog ver.2.6, Macropod Software). For each session, the duration of foraging, the frequency of swallowing and walking (the number of steps), and the composition of prey species were recorded for each habitat category. The seasonal use of foraging habitats was evaluated based on the sum of the duration of each foraging session in each habitat category for each season. We considered that the total duration of use of each habitat calculated from observations made on four days every two weeks would reveal the seasonal pattern of foraging habitat use.

Prey species were categorised as loach, earthworm, and small invertebrates that could not be identified by direct observation using a telescope. These unknown small invertebrates were assigned to aquatic and/or terrestrial invertebrates according to the habitat in which each prey was captured. All loaches were the oriental weatherloach Misgurnus anguillicaudatus, the most frequent species in paddies of Japan. The earthworm category contained several species of Megascolecidae, Lumbricidae, and Moniligastridae but we could not identify each species. The rate of prey capture was calculated as the number of each prey item (loach, earthworm, and small invertebrate) divided by foraging duration (in minutes). For each type of prey, the rate of prey capture was compared between seasons and habitat.

\section{Data analysis}

A chi-squared test was used to detect differences in the foraging habitats used and the composition of prey species among seasons. To examine the effect of five seasons, foraging habitats, and the interaction term 'foraging habitat $\times$ season' on the rate of prey capture, generalised linear models (GLMs) assuming a Gaussian distribution and using identity as link function performed separately for each prey category. Analysis of deviance of GLM models with chi-squared tests was used to detect the significance of each factor. When significant interaction between foraging habitats and season existed, a multiple comparison test ("kruskalmc" in "pgirmess" package in R) after a Kruskal-Wallis test was used to compare the rate of prey capture among foraging habitats separately for each season. For the comparison among foraging habitats, habitat types with less than three observation of prey capture were removed from the analysis. Statistical analyses were conducted using JMP version 5.0.1 (SAS Institute Inc., Cary, NC) and R 2.8.I (The R foundation for Statistical Computing).

\section{Results}

The proportional use of habitats was significantly different among the five seasons $\left(\chi^{2}=164,193\right.$, $\mathrm{df}=20, P<0.0001$, Figure 1 ). Paddies were the main foraging habitat in spring, early summer, autumn, and winter. In late summer, Japanese Crested Ibis often used levees around paddies, 


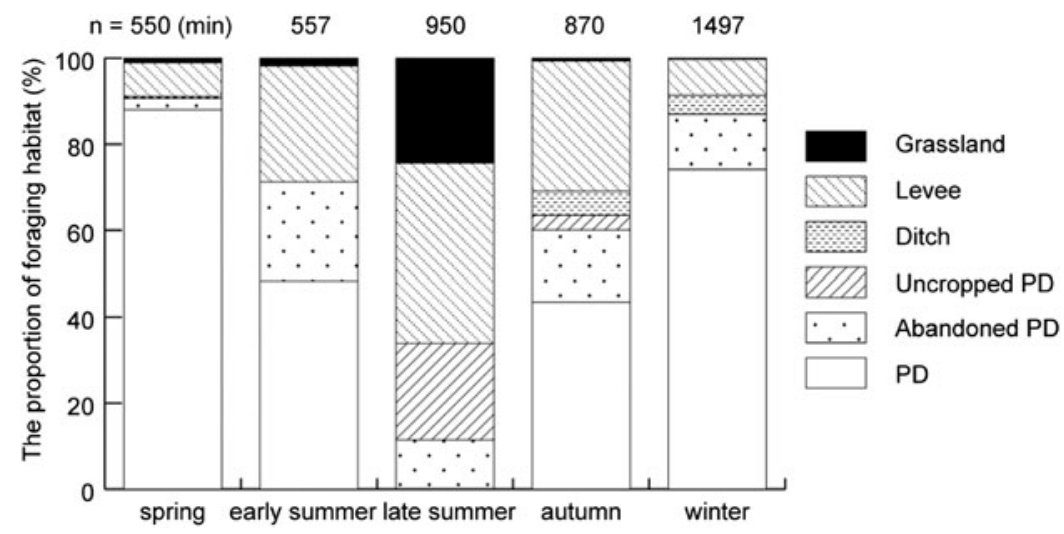

Figure 1. Seasonal changes in foraging habitats used by Japanese Crested Ibis. Five seasons were categorised based on the proportion of seasonal use of paddy and agricultural schedule for cultivating rice plants (see text for details).

grasslands and uncropped paddies. Abandoned paddies were used between early summer and winter. Loaches and earthworms represented $3-17 \%$ and $1-13 \%$ of total prey consumed throughout the seasons, respectively (Figure 2). The proportions of prey species were different between seasons $\left(\chi^{2}=2,108, \mathrm{df}=16, P<0.0001 ;\right.$ Figure 2$)$. In late summer, earthworms and terrestrial invertebrates comprised the highest proportion of total prey compared with the other seasons. Small aquatic and terrestrial invertebrates represented $70-90 \%$ of total prey across all seasons.

For each prey category, analysis of deviance of GLM models indicated that foraging habitat, season, and the interaction foraging habitat $X$ season significantly affected the rate of prey capture (Table 1). The capture rate of loaches in late summer and autumn was higher in uncropped paddy than in abandoned paddy (Table 2a). The capture rate of loaches in winter was higher in ditch and paddy than in abandoned paddy. The capture rate of earthworms in early and late summer was higher in levee than in paddy and uncropped paddy (Table $2 b$ ). The capture rate of small invertebrates in spring was higher in paddy than in levee (Table 2c). The capture rate of small invertebrates in late summer was higher in abandoned paddy, levee and grassland than in uncropped paddy. The capture rate of small invertebrates in autumn was higher in abandoned

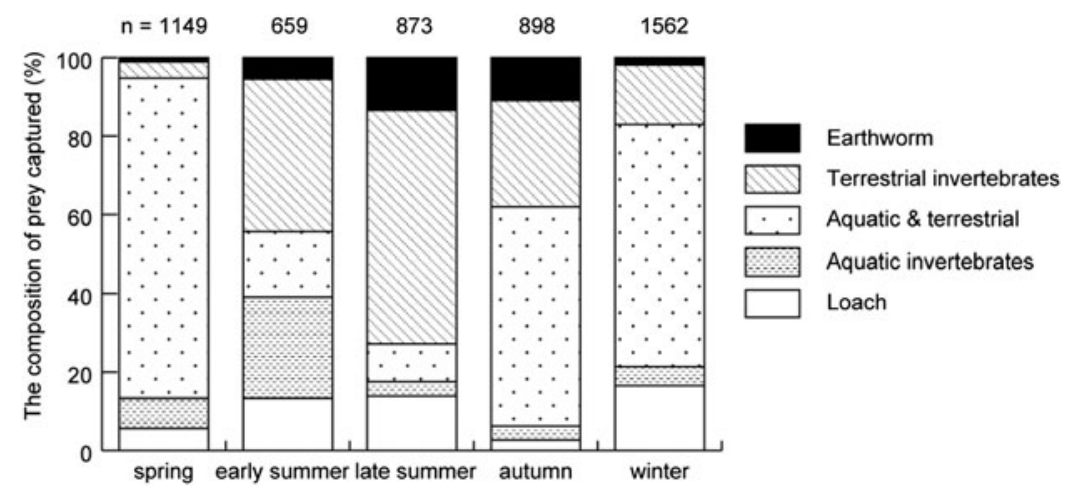

Figure 2. Seasonal changes in the composition of prey captured by Japanese Crested Ibis. Small prey items which could not be identified by direct observation were sorted into terrestrial, aquatic and both terrestrial and aquatic invertebrates according to each foraging habitat. 
Table 1. Analysis of deviance of explanatory variables in GLM models with chi-square test for the capture rates in the six foraging habitat of the season for each prey category.

\begin{tabular}{|c|c|c|c|c|c|c|c|c|c|c|c|c|c|c|c|}
\hline \multirow[t]{2}{*}{ Factor } & \multicolumn{5}{|c|}{ Loach } & \multicolumn{5}{|c|}{ Earthworm } & \multicolumn{5}{|c|}{ Small invertebrates } \\
\hline & $\mathrm{df}$ & Deviance & Resid. $\mathrm{df}$ & $\begin{array}{l}\text { Resid. } \\
\text { Deviance }\end{array}$ & $P$ & $\mathrm{df}$ & Deviance & Resid. df & $\begin{array}{l}\text { Resid. } \\
\text { Deviance }\end{array}$ & $P$ & $d f$ & Deviance & Resid. $d f$ & $\begin{array}{l}\text { Resid. } \\
\text { Deviance }\end{array}$ & $P$ \\
\hline Null & & & 794 & 98.21 & & & & 794 & 34.26 & & & & 794 & 839.68 & \\
\hline Season & 4 & 2.08 & 790 & 96.12 & $* * *$ & 4 & 1.03 & 790 & 33.23 & $* * *$ & 4 & 70.79 & 790 & 768.89 & $* * *$ \\
\hline Foraging habitat & 5 & 8.46 & 785 & 87.66 & $* * *$ & 5 & 1.25 & 785 & 31.98 & $* * *$ & 5 & 16.99 & 785 & 751.90 & $* * *$ \\
\hline Season $\times$ foraging habitat & 8 & 3.43 & 777 & 84.22 & $* * *$ & 8 & 1.80 & 777 & 30.18 & $* * *$ & 8 & 40.57 & 777 & 711.33 & $* * *$ \\
\hline
\end{tabular}

df Degree of freedom

${ }^{* * *} P<0.001$ 
Table 2. Comparison of capture rates among foraging habitats in each season (a) No. of loach captured per min (SE), (b) No. of earthworm captured per min (SE), (c) No. of small invertebrates captured per min (SE).

\begin{tabular}{|c|c|c|c|c|c|c|c|c|c|c|}
\hline & \multicolumn{6}{|l|}{ Habitat type } & \multirow[t]{2}{*}{$\mathrm{df}$} & \multirow{2}{*}{ chi-squared } & \multirow{2}{*}{$P$} & \\
\hline & PD & AbandonedPD & UncroppedPD & Ditch & Levee & Grassland & & & & \\
\hline spring & $0.13(0.04)$ & - & - & - & o & - & 1 & 2.66 & n.s. & \\
\hline early summer & 0.17 (0.14) & $0.21(0.14)$ & - & - & o & - & 2 & 13.75 & $* *$ & $\mathrm{PD}>\mathrm{LV}$ \\
\hline late summer & - & 0.21 (0.10) & 0.47 (0.10) & - & o & o & 3 & 85.93 & $* * *$ & UPD > APD \\
\hline autumn & $0.03(0.02)$ & $0.05(0.03)$ & $0.14(0.07)$ & $\mathrm{o}$ & $\mathrm{o}$ & - & 4 & 20.81 & $* * *$ & \\
\hline winter & 0.16 (0.15) & $0.12(0.25)$ & - & $1.12(0.27)$ & o & - & 3 & 25.00 & $* * *$ & DT, PD > LV \\
\hline \multicolumn{11}{|l|}{ (b) } \\
\hline & \multicolumn{6}{|l|}{ Habitat type } & \multirow[t]{2}{*}{ df } & \multirow[t]{2}{*}{ chi-squared } & \multirow[t]{2}{*}{$P$} & \\
\hline & PD & AbandonedPD & UncroppedPD & Ditch & Levee & Grassland & & & & \\
\hline spring & 0.005 (0.01) & - & - & - & $0.03(0.02)$ & - & 1 & 1.52 & n.s. & \\
\hline early summer & 0.01 (0.08) & $0.05(0.08)$ & - & - & $0.14(0.07)$ & - & 2 & 20.00 & $* * *$ & $\mathrm{LV}>\mathrm{PD}$ \\
\hline late summer & - & 0.06 (0.09) & o & - & $0.21(0.06)$ & 0.06 (0.07) & 3 & $25 \cdot 56$ & $* * *$ & $\mathrm{LV}>\mathrm{UPD}$ \\
\hline autumn & $0.05(0.05)$ & 0.28 (0.06) & o & o & $0.07(0.06)$ & - & 4 & 18.33 & $* *$ & \\
\hline winter & $0.003(0.02)$ & 0.008 (0.04) & - & o & 0.05 (0.03) & - & 3 & 2.41 & n.s. & \\
\hline \multicolumn{11}{|l|}{ (c) } \\
\hline & \multicolumn{6}{|l|}{ Habitat type } & \multirow[t]{2}{*}{ df } & \multirow[t]{2}{*}{ chi-squared } & \multirow[t]{2}{*}{$P$} & \\
\hline & PD & AbandonedPD & UncroppedPD & Ditch & Levee & Grassland & & & & \\
\hline spring & $1.91(0.4)$ & - & - & - & $0.66(0.57)$ & - & 1 & 16.28 & $* * *$ & $\mathrm{PD}>\mathrm{LV}$ \\
\hline early summer & $0.31(0.25)$ & $0.77(0.25)$ & - & - & $0.94(0.21)$ & - & 2 & 0.23 & n.s. & \\
\hline late summer & - & 0.90 (0.16) & $0.17(0.16)$ & - & $0.77(0.11)$ & $0.52(0.13)$ & 3 & 35.67 & $* * *$ & APD, LV, GL > UPD \\
\hline autumn & $0.77(0.17)$ & $1.42(0.22)$ & $0.12(0.48)$ & $0.56(0.48)$ & $0.68(0.21)$ & - & 4 & 11.27 & * & $\mathrm{APD}>\mathrm{UPD}$ \\
\hline winter & $0.90(0.17)$ & $0.23(0.28)$ & - & $1.30(0.31)$ & $0.51(0.23)$ & - & 3 & 22.01 & $* * *$ & $\mathrm{DT}, \mathrm{PD}>\mathrm{LV}$ \\
\hline
\end{tabular}

Multiple comparison test after Kruskal-Wallis test.

*** $P<0.001,{ }^{* *} P<0.01,{ }^{*} P<0.05$.

PD paddy, APD AbandonedPD, UPD UncroppedPD, DT Ditch, LV Levee, GL Grassland. 
paddy than in uncropped paddy. The capture rate of small invertebrates in winter was higher in ditch and paddy than in levee.

\section{Discussion}

From May to early July (early summer), the main foraging habitats were paddies and abandoned paddies where shallow water was retained, and the proportion of aquatic organisms in the total prey was higher than at any other time during the year. From late July to September, ibises did not use paddies as foraging habitats. They often used grasslands and levees around paddies, and they mainly captured terrestrial invertebrates, including earthworms. This probably reflected seasonal changes in the relative availability of habitats and prey abundance in fields. During late summer, the height and density of rice plants seemed to prevent ibises from entering paddies, as was suggested by Nagata (2010). In summer, Cattle Egrets Bubulcus ibis, Intermediate Egrets Egretta intermedia, and Little Egrets E. garzetta used flooded open fields (fallow fields), not paddies, in Japan (Fujioka et al. 2001). Herons often made heavy use of paddies, except during the breeding season in summer (Pierluissi 2010). These results suggest that when rice is growing and stalk density is high, the use of paddies by birds tends to reach an annual low (Elphick 2010). A peak in the abundance of aquatic organisms was found in June, whereas the peak abundance of terrestrial organisms was found in August and September in paddies, including levees around paddies, on Sado Island (Oh-ishi et al. in litt.). Seasonal changes in the pattern of foraging habitat use seem to coincide with seasonal changes in prey abundance. After harvest, the availability of paddies generally becomes high because rice plants are cut and human agricultural activities are reduced; therefore, ibises can use paddies as their main foraging habitat. During this season, most of the paddies are drained, but parts of paddies are sometimes covered with water. Ibises prefer to forage in these water patches.

Ibises captured loaches throughout the year (less than $20 \%$ of prey captured), and the capture rate tended to differ among habitat types (Table 2). Especially in winter, the capture rate of loaches was higher in ditches and paddy than in abandoned paddies. In winter, loaches often escape from dry paddies to ditches, where shallow water is retained throughout the year (Kano et al. 2010). Ditches are therefore suitable foraging habitats where ibises can catch loaches in winter. Ibises depend on terrestrial invertebrates, including earthworms, in late summer, when grasslands and levees around paddies appear to be important foraging habitats. Small invertebrates were an important prey component of the ibis in terms of frequency (70-90\%) throughout the year. Loaches are the most important prey for the Japanese Crested Ibis in terms of biomass and calorific intake. However, both aquatic and terrestrial small invertebrates are also important prey in terms of seasonal availability and presumably for essential nutrients (unpublished data from captive ibises). More precisely, we need to evaluate habitat conditions and foraging efficiency based on energy intake because ibises exploit a variety of aquatic and terrestrial organisms. Further work is required to determine whether the foraging trends observed in this study remain consistent from year to year and with higher population levels.

The success of the reintroduction of Japanese Crested Ibis depends on whether the factors affecting the original decline have been removed or reversed (IUCN 1998, reviewed in Fischer and Lindenmayer 2000). We need to consider seasonal changes in foraging habitats specific to agricultural practices in Japan for the conservation of the foraging habitats of Japanese Crested Ibis. In late summer, management of grass height on levees and grasslands will be effective in ensuring the availability of foraging habitats. No clear correlation between the rate of capture of each prey and the proportion of habitats used in each season were detected. However, abandoned paddies and uncropped paddies appear to be suitable habitats for ibises because the level of human disturbance was relatively low and the rate of capture for each prey was relatively high throughout the year in the present study. We should examine the relationship between the proportional use of habitats and foraging efficiency (based on energy intake), as was suggested by Lombardini et al. (2001) and Davison and Fitzpatrick (2010). 
Sado city government is encouraging farmers to change their usual rice production method to a certified ibis-friendly system, based on organic farming. Several other options are proceeding (water management practices in paddies, such as retaining shallow water during the winter, creating ditches inside paddies, and creating connections between paddies and waterways to increase fish movement) with the aim of increasing biodiversity during the process of regenerating farmland ecosystems, including the establishment of Japanese Crested Ibis populations. Our results showed that increasing biodiversity in paddies and creation of ditches were effective in improving the quality of foraging habitat for Japanese Crested Ibis. In addition to the certified rice production system in Sado, we suggest that managing the height of grass on levees and grassland during summer is an effective habitat management strategy. Consideration of appropriate management of abandoned paddies and uncropped paddies would be also essential for the successful reintroduction of the Japanese Crested Ibis.

Although it is early in the reintroduction programme, it is important to evaluate the seasonal availability of suitable foraging habitats for the ibis at the current stage, and to build up an adaptive management strategy to protect and regenerate suitable areas. These procedures for evaluating seasonal availability of foraging habitats and prey species with consideration of agricultural management will also be effective for the conservation of various avian species in farmland areas.

\section{Acknowledgements}

We appreciate the co-operation with the research from farmers on Sado Island and the ibis Monitoring Team organised by the staff of Sado Office of the Ministry of the Environment Government of Japan, Japan Wildlife Research Center, Niigata University, and citizens of Sado. T. Sekijima, U. Nishikawa, T. Funo and anonymous referees provided useful comments on the manuscript. This work was financially supported by the Global Environmental Research Fund of the Ministry of the Environment, Japan (Subject No. F-072) and Toki Project of Center for Transdisciplinary Research of Niigata University.

\section{References}

Amano, T., Kusumoto, Y., Tokuoka, Y., Yamada, S., Kim, E. Y. and Yamamoto, S. (2008) Spatial and temporal variations in the use of rice-paddy dominated landscapes by birds in Japan. Biol. Conserv. 141: 17041716.

Armstrong, D. P. and Seddon, P. J. (2007) Directions in reintroduction biology. Trends Ecol. Evol. 23: 20-25.

BirdLife International (2001) Crested ibis. Threatened birds of Asia: the Birdlife International Red Data Book. Cambridge, UK: BirdLife International.

Davison, M. A. and Fitzpatrick, J. W. (2010) Role of human-modified habitat in protecting specialist species: A case study in the threatened Florida Scrub-Jay. Biol. Conserv. 143: 2815-2822.

Elphick, C. S. (2010) Why study birds in rice fields? Waterbirds 33 (special publication 1): $1-7$.
Fischer, J. and Lindenmayer, D. B. (2000) An assessment of the published results of animal relocations. Biol. Conserv. 96: 1-11.

Fujioka, M., Armacost, J. W., Yoshida, H. and Maeda, T. (2001) Value of fallow farmlands as summer habitats for waterbirds in a Japanese rural area. Ecol. Res. 16: 555567.

Fujioka, M., Lee, S. D., Kurechi, M. and Yoshida, H. (2010) Bird use of rice fields in Korea and Japan. Waterbirds 33 (special publication 1): 8-29.

IUCN (1998) Guidelines for re-introductions. IUCN/SSC Re-introduction Specialist Group. IUCN (http://www.iucnsscrsg.org/)

Kano, Y., Kawaguchi, Y., Yamashita, T. and Shimatani, Y. (2010) Distribution of the oriental weatherloach, Misgurnus anguillicaudatus, in paddies and its implications for conservation in Sado Island, Japan. Ichthyol. Res. 57: 180-188. 
Li, X., Li, D., Li, Y., Ma, Z. and Zhai, T. (2002) Habitat evaluation for crested ibis: A GISbased approach. Ecol. Res. 17: 565-573.

Li, X., Tian, H. and Li, D. (2009) Why the crested ibis declined in the middle twentieth century. Biodivers. Conserv. 18: 2165-2172.

Lombardini, K., Bennetts, R. E. and Tourenq, C. (2001) Foraging success and foraging habitat use by Cattle egrets and Little egrets in the Camargue, France. The Condor 103: 38-44.

Maeda, T. (2001) Patterns of bird abundance and habitat use in rice fields of the Kanto
Plain, central Japan. Ecol. Res. 16: 569585.

Nagata, H. (2010) Dispersal and foraging behaviours of re-introduced Crested ibis Nipponia nippon in Sado Island. Kankyokenkyu 158: 69-74. (In Japanese).

Pierluissi, S. (2010) Breeding waterbirds in rice fields: a global review. Waterbirds 33 (special publication 1): 123-132.

Yamashina, Y. and Nakanishi, G. (1983) Newton Books: Nipponia nippon. Kyoikusha, Tokyo (in Japanese).

\section{CHIHIRO ENDO*, HISASHI NAGATA}

Center for Toki \& Nature Restoration, Niigata University, Ikarashi Ninocho 8050, Nishi, Niigata, 950-2181 Japan.

*Author for correspondence; e-mail: chihiro.endo.zzz@gmail.com

Received I May 2011; revision accepted 12 October 2011;

Published online 23 November 2012 